International Journal of Management Science and Business Administration

Volume 7, Issue 4, May 2021, Pages 36-44

DOI: $10.18775 /$ ijmsba.1849-5664-5419.2014.74.1005

URL: http://dx.doi.org/10.18775/ijmsba.1849-5664-5419.2014.74.1005

\title{
Uses and Gratifications of Political Information: Student Perceptions of Information from the 2014 Tunisian Elections
}

\author{
${ }^{1}$ Steven D. Sheetz, ${ }^{2}$ Andrea Kavanaugh, ${ }^{3}$ Hamida Skandrani, ${ }^{4}$ Edward A. Fox \\ ${ }^{1}$ Department of Accounting \& Information Systems \\ Pamplin College of Business \\ Virginia Tech, Blacksburg, VA, USA \\ ${ }^{2}$ Center for Human-Computer Interaction \\ Virginia Tech, Blacksburg, VA, USA \\ ${ }^{3}$ Department of Management \\ High Institute of Accounting and Business Administration (ISCAE) \\ University of Manouba, Manouba, Tunisia \\ ${ }^{4}$ Department of Computer Science \\ Virginia Tech, Blacksburg, VA, USA
}

\begin{abstract}
People use diverse sources of information to obtain political information. We apply uses and gratifications theory (UGT) to illustrate how the use of different political information sources influences perceptions of information satisfaction related to the Tunisian elections of 2014. An online survey of 175 university students in Tunisia, with a $58 \%$ response rate. We use partial least squares structural equation modelling to test our research model of hypotheses relating content, process, and social gratifications to information satisfaction. We find that content, process, and social gratifications constructs combine to explain $41 \%$ of the variance in information satisfaction. Content gratification has the strongest influence $(\mathrm{p}=.505)$ followed by similar levels of influence of process $(\mathrm{p}=.163)$ and social $(\mathrm{p}=.140)$ gratifications. Social gratifications are partially mediated by process gratification. Limitations of our study include our online survey method and our sample of university students. However, our respondents experienced the uprising, the election campaigns, and voted in the elections, suggesting their perceptions are valid, if not generalisable to all of Tunisia. Practically our study suggests that individuals searching for political information should 1) determine how they'll know information is accurate, 2) maximize the number of different activities for information-seeking rather than focusing on the frequency of a few activities, and 3) know that information sharing contributes to information satisfaction. The dominance of content gratifications, i.e., information reliability and accuracy, is important for information providers, such as, government and political leaders. Our study provides evidence that UGT is useful in the novel context of emerging political situations.
\end{abstract}

Keywords: Uses and gratifications theory, Social media, Political informatics, Structural equation modelling

\section{Introduction}

The popular uprisings that brought down the authoritarian government in Tunisia in 2011 resulted in a new constitution and elections in 2014. Largely considered free and fair, these elections were historic as they replaced a regime in place since 1987 and posited a democratic future for Tunisia. As the election occurred, many different groups attempted to influence citizens' perceptions through various information and communication technologies.

Information and communication technology (ICT) includes television, radio, newspapers and magazines, telephone networks (including cell systems), and the Internet, including social media. In this study we focus on using services from the Internet, cell phone communications, and traditional media sources, e.g., TV, newspapers and face-to-face (F2F) communication. Our goal is to understand how these sources of information are used to satisfy peoples' needs for information related to political events. In this paper, we examine the use of these information sources by an opportunity sample of young Tunisians during the Tunisian elections of 2014. 
Uses and gratifications theory (UGT) describes how information users meet their information needs. Originally proposed when TV was new (Katz and Lazarsfeld 1955), UGT was applied recently to assess the Internet (Stafford, Stafford et al. 2004), social media (Ku, Chu et al. 2013), and political information (Kaye and Johnson 2002, Kaye and Johnson 2004). UGT describes how information is accessed (through the use of technology and media) and why a source of information is used (to satisfy an information need, i.e., gratification). Stafford et al. (2004) and others (Ruggiero 2000) summarise the gratifications derived from using the Internet as:

1. Content (the information in the message), and

2. Process (the information-seeking activities from traditional UGT), and

3. Social gratifications as an additional construct defined to integrate using the internet for communication and social networking.

Applications of UGT to social media are consistent with this perspective, most often focusing on a subset of gratifications drawn from information seeking and social gratifications constructs.

Using partial least squares based structural equation modelling (PLS-SEM), we show that the expectations for significant positive influences of traditional UGT constructs of content, process, and social gratifications hold in our context of difficult elections, explaining a substantial amount of variance in our information satisfaction construct (R2 $=.41$ ) and having significant positive influences on information satisfaction.

\section{Theoretical Framework and Hypotheses Development}

\subsection{Prior research applying Uses and Gratifications Theory}

The number, diversity and reliability of political information sources (TV, newspapers, Internet) throughout Tunisia expanded after the uprising in the run-up to the 2014 elections as governmental controls were reduced in the period. Also, social network sites (SNS), such as Facebook (FB), Twitter, and photo/video sharing websites were also becoming more popular. For example, early in 2011 FB use was $17.6 \%$, and nearly doubled to $33.9 \%$ by 2013. (Salem, 2014). The diversity of information sources is indicated by a high ownership of cell phones, availability of the Internet, and increases in social media use which may have contributed to enhanced access to and sharing of information related to the 2014 elections.

Uses and gratifications theory has a long history in the study of mass communication (Katz and Lazarsfeld 1955, Katz, Blumler et al. 1973). UGT argues that people use different communication media to fulfill (i.e., gratify) different needs, such as, information-seeking, social interaction, relaxation, entertainment, passing time, and companionship (Katz 1987). Our study draws on research applying UGT to the use of traditional media (TV, newspapers, radio) versus the Internet, including social media, for the gratification of political information seeking.

Stafford et al. (2004) identify a SEM model consisting of three constructs, including content gratifications, process gratifications, and social gratifications. Content and process gratifications are defined as: "Content gratifications concern the messages carried by the medium, and process gratifications concern actual use of the medium itself." (Cutler and Danowski 1980). They include social gratifications due to the nature of communication over the Internet. This construct is also consistent with research on UGT in the context of social media. They then test the measurement model, finding a good fit of their indicators with these constructs in the context of Internet use and confirming the relevance of the social gratifications construct.

We adopt the content, process, and social gratifications construct naming of Stafford et al. (2004) because they find a good fit for these constructs for modelling uses of the Internet. Perceptions of information accuracy and reliability are consistent with the content gratifications construct, while web browsing and surfing are part of the process gratifications construct. Finally, their social gratifications construct includes interactions with friends and other people using technology. These three constructs are consistent with our interest in how information is obtained related to political situations, including elections, in emerging countries.

Recent UGT research on using the Internet and political information show that the constructs we adopt are consistent with the constructs studied previously. In the following section, we briefly summarise the research in each of these areas.

Permalee and Perkins (Parmelee and Perkins 2012), performed a qualitative study that includes "word of mouth" and UGT constructs of information seeking and social utility. Comments show participants went online after suggestions from social ties, consistent with using their social network to filter information. Participants' information-seeking activities on the Internet were focused on obtaining additional details on topics seen in traditional broadcast media, e.g., newspapers or TV. Participants' perceptions of media credibility triggered searches that included traditional media websites representing ideological diversity and politically diverse opinion. 
Muhtaseb and Frey (Muhtaseb and Frey 2008) apply UGT to Arab Americans' use of the Internet and other media. Their online survey reveals that the Internet is a viable alternative to other media for information-seeking and interpersonal interaction for these respondents.

Lin (Lin 2002) studies gratifications of online services and traditional broadcast media, including television, newspapers for informational learning (content), entertainment (process), and interaction (social). They use regression analysis to find that information seeking and the interaction experiences are significant, predicting $39 \%$ of the likelihood of media service access.

UGT has been applied to political information and understanding political interests. Kaye and Johnson (Kaye and Johnson 2002) found the UGT motivations of guidance, information seeking and surveillance, entertainment, and social utility significant for seeking political information online -- indicating that information seeking and surveillance are related to greater political interest.

Kaye and Johnson (Kaye and Johnson 2004) identify four factors motivating political activity and social media, including guidance, social utility, convenience, and information seeking. They find that political involvement, years online, and the number of online activities as more significant predictors of these motivations -- suggesting that those who are interested in politics trust Internet-based political information.

Macafee (Macafee 2013) investigates the use of traditional and social media for political engagement. They evaluate the use of social media features of commenting, posting links, posting status updates about issues, and liking political candidates/causes. They found that participants used Facebook to engage socially and share information with other users. Those that were involved politically in other activities also used Facebook for interacting on political issues. The frequency of Facebook use is the only significant variable that explains moderate variance of each of these activities; $\mathrm{TV}$, newspapers, and Internet news were not significant.

Chung, Nam et al. (Chung, Nam et al. 2012) compare traditional and technological factors for determining online news credibility. They found that traditional factors of trustworthiness and expertise are the only significant factors driving the use of online news sites of established news sources. While technological factors, interactivity, hypertextuality, and multimodality do not significantly contribute to credibility.

In summary, these studies that apply UGT to the Internet, social media, and political news use constructs consistent with the content, process, and social gratifications constructs described by Stafford et al. (2004). Our model also is based on these constructs.

\subsection{Hypotheses}

We extend the model including only UGT constructs by adding the information satisfaction construct used in prior research (Bailey and Pearson 1983, McKinney, Yoon et al. 2002, Wixom and Todd 2005) and hypotheses that relate each type of gratification to this dependent variable. We define information satisfaction as consisting of dimensions of information availability, Internet information importance, and traditional source information importance. Table 1 presents the construct definitions for our model.

Information availability refers to being able to access the information needed and feeling as though you know what is happening politically; higher perceptions of availability are indications of higher satisfaction with the information received. Information importance also is a dimension of information satisfaction. We expect that when people believe the information they have obtained is more important, they are more satisfied with that information.

We test hypotheses relating the UGT constructs to information satisfaction. Also, we test whether social gratifications influences of process gratifications. This results in four hypotheses:

H1: Content gratifications have a positive influence on information satisfaction.

$\mathrm{H} 2$ : Process gratifications have a positive influence on information satisfaction.

H3: Social gratifications has a positive influence on information satisfaction.

H4: Social gratifications have a positive influence on process gratifications.

Table 1: Construct Definitions: Content, Process, and Social Gratifications, and Information Satisfaction

\begin{tabular}{|l|l|}
\hline Panel A: Uses and Gratifications Constructs \\
\hline Content Gratifications deriving from the information/messages obtained \\
\hline Internet & The degree to which the information/messages the participant obtained through the Internet related to the \\
Source & elections was reliable. \\
Reliability & \\
\hline
\end{tabular}




\begin{tabular}{|c|c|}
\hline $\begin{array}{l}\text { Traditional } \\
\text { Source } \\
\text { Reliability }\end{array}$ & $\begin{array}{l}\text { The degree to which the information/messages the participant obtained through traditional sources related } \\
\text { to the elections was reliable. }\end{array}$ \\
\hline \multicolumn{2}{|c|}{ Process Gratifications deriving from the use of the Internet } \\
\hline $\begin{array}{l}\text { Internet } \\
\text { Frequency }\end{array}$ & $\begin{array}{l}\text { The frequency with which participants use the Internet for getting information about the elections, } \\
\text { including the frequency of using video, social media, and Internet news sites. }\end{array}$ \\
\hline $\begin{array}{l}\text { Internet } \\
\text { Information } \\
\text { Activities }\end{array}$ & $\begin{array}{l}\text { The number of activities used related to Internet information on the elections, including the number } \\
\text { of actions performed with cell phones, the social media features used, and types of Internet sites } \\
\text { visited. }\end{array}$ \\
\hline $\begin{array}{l}\text { Traditional } \\
\text { Information } \\
\text { Activities }\end{array}$ & $\begin{array}{l}\text { The number of activities used related to traditional information on the elections. Including the } \\
\text { number of actions TV stations watched, radio stations, and types of F2F interactions. }\end{array}$ \\
\hline \multicolumn{2}{|c|}{ Social Gratifications deriving from the social environment } \\
\hline $\begin{array}{l}\text { Sharing } \\
\text { Internet } \\
\text { Informaiton }\end{array}$ & $\begin{array}{l}\text { The degree to which the participant shares (receives) information obtained from the Internet with } \\
\text { (from) her/his family and friends. }\end{array}$ \\
\hline $\begin{array}{l}\text { Internet } \\
\text { Sharing } \\
\text { Frequency }\end{array}$ & $\begin{array}{l}\text { The frequency with which the participant shares information obtained from Internet sources, e.g., } \\
\text { SNS, email, and cell phone, with her/his family and friends. }\end{array}$ \\
\hline $\begin{array}{l}\text { Traditional } \\
\text { Sharing } \\
\text { Frequency }\end{array}$ & $\begin{array}{l}\text { The frequency with which the participant shares information obtained from traditional sources, e.g., } \\
\text { F2F and phone, with her/his family and friends. }\end{array}$ \\
\hline \multicolumn{2}{|c|}{ Panel B: Information Satisfaction Constructs } \\
\hline $\begin{array}{l}\text { Internet } \\
\text { Source } \\
\text { Importance }\end{array}$ & $\begin{array}{l}\text { The degree the information they obtained through the Internet was important for influencing her/his } \\
\text { thinking about political events. }\end{array}$ \\
\hline $\begin{array}{l}\text { Traditional } \\
\text { Source } \\
\text { Importance }\end{array}$ & $\begin{array}{l}\text { The degree the information they obtained through traditional sources was important for influencing } \\
\text { her/his thinking about political events. }\end{array}$ \\
\hline $\begin{array}{l}\text { Information } \\
\text { Availability }\end{array}$ & $\begin{array}{l}\text { The degree to which the participant was able to obtain all the information he/she needed and wanted } \\
\text { from all sources. }\end{array}$ \\
\hline
\end{tabular}

These four hypotheses are derived from the results of UGT studies of the Internet, and political information discussed above. Figure 1 presents our research model.

Figure 1: Uses and Gratifications Research model for Political Information

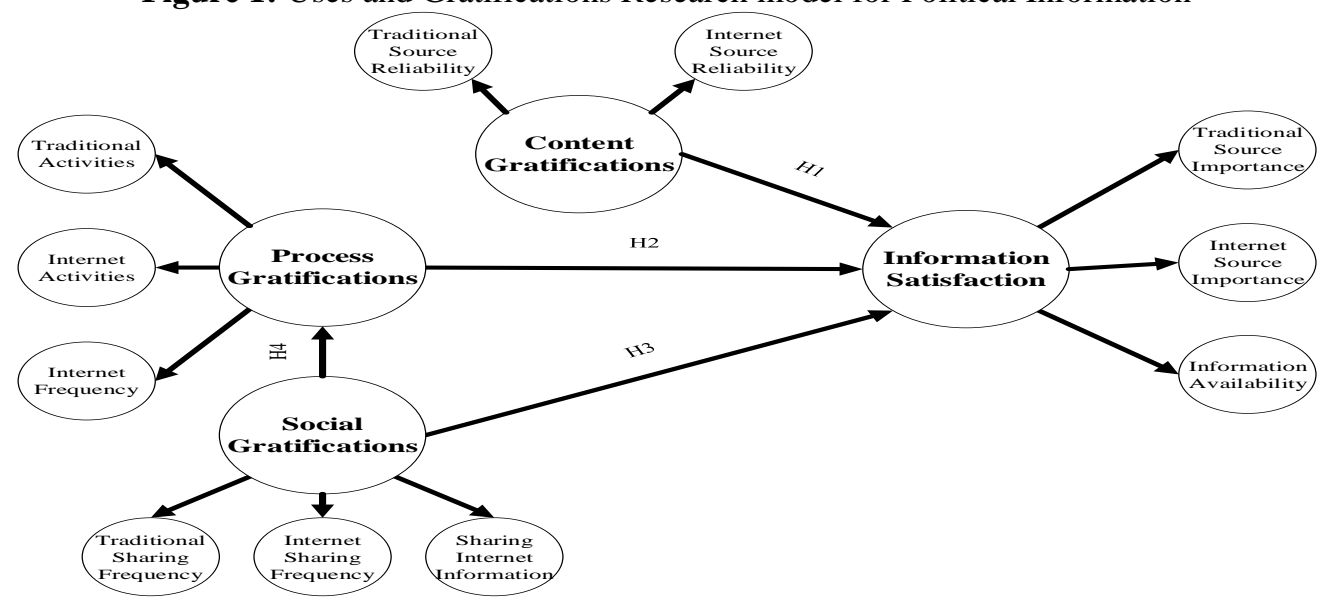




\section{Methodology}

We adapted the survey from items used in previous studies applying UGT to investigate the use of the Internet and social media in particular (Kraut, Kiesler et al. 2002). Then we sent via email an invitation to participate in the survey for extra course credit or equivalent assignments to 330 students at a large university in Tunisia. Students completed our online survey, which was transcribed into French.

Our procedures for the web-based survey were consistent with the guidelines recommended by Punter, et al. (Punter, Ciolkowski et al. 2003) and (Singer and Vinson 2002) for online software engineering surveys. Consistent with Bryant et al. (2004), we included controls to account for internal validity threats such as increased dropout rates and multiple submissions from the same participant.

\section{Results}

The data were collected in April and May 2015, about nine months after the elections. The survey was sent to 330 potential participants; 204 participants attempted the survey, and 175 completed it, for a $58 \%$ response rate. The mean age was 22 years old, and most (90\%) were 19-27 years old. More females (76\%) than male respondents; most (86\%) were single. Most (90\%) had been using the Internet for less than ten years, with a mean of 7.4 years. Fifty-five per cent were pursuing an undergraduate degree, $37 \%$ were pursuing graduate degrees, and $8 \%$ were pursuing technical or commercial degrees.

We use partial least squares structural equation modelling (PLS-SEM) to test our research model (Gopal, Bostrom et al. 1992). The PLS-SEM measurement and structural models were assessed using smart PLS version 2.0 beta (Ringle, Wende et al. 2005).

\subsection{Measurement Properties}

Scale reliabilities, along with convergent and discriminant validity were assessed for our first order reflective constructs. Scale reliability was assessed via composite reliability and Cronbach's alpha (Fornell and Larcker 1981). Table 2 contains the results of these analyses. Composite reliabilities are above the recommended 0.70 level, and Cronbach's alphas for the traditional activities at .50 and Internet sharing frequency at .58 constructs are lower than desired. (Agarwal and Karahanna 2000; Staples and Seddon 2004).

Table 2: Construct means, standard deviations, and measures of internal consistency

\begin{tabular}{|l|l|r|r|r|r|r|}
\hline Construct & $\begin{array}{l}\# \\
\text { Items }\end{array}$ & Mean & Std. Dev. & AVE & $\begin{array}{r}\text { Composite } \\
\text { Reliability }\end{array}$ & $\begin{array}{r}\text { Cron.'s } \\
\text { Alpha }\end{array}$ \\
\hline & & & & & & \\
\end{tabular}

We tested convergent validity, by determining whether the average variance extracted (AVE) is greater than or equal to 0.50 for each construct (Chin 1998). Our first order reflective constructs meet this requirement, except for Internet activities at .49, as shown in Table 2. 
We also established both discriminant and convergent validity of these constructs using an AVE test (Fornell and Larcker 1981) (Netemeyer, Johnston et al. 1990), ensuring that the AVE values for the two constructs are greater than the correlation of the two constructs. Table 3 presents these values.

Table 3: Construct correlations and square-root of AVE values on diagonal.

\begin{tabular}{|c|r|r|r|r|r|r|r|r|r|r|r|}
\hline & ActInter & ActTrad & Content & ConTrad & IntFreq & ImpTrad & ImpInt & Satis & ShrInt & shInt & shTrad \\
\hline ActInternet & $\mathbf{. 7 0}$ & & & & & & & & & & \\
\hline ActTrad & 0.542 & $\mathbf{. 7 1}$ & & & & & & & & & \\
\hline Content & 0.143 & 0.006 & $\mathbf{. 8 1}$ & & & & & & & & \\
\hline & & & & & & & & & & & \\
ContentTrad & 0.111 & 0.119 & 0.445 & $\mathbf{. 7 6}$ & & & & & & & \\
\hline Frequency & 0.44 & 0.295 & 0.245 & 0.141 & $\mathbf{. 7 1}$ & & & & & & \\
\hline & & & & & & & & & & & \\
ImportTrad & 0.317 & 0.227 & 0.484 & 0.365 & 0.364 & $\mathbf{. 7 3}$ & & & & \\
\hline Importance & 0.055 & 0.097 & 0.305 & 0.466 & 0.164 & 0.524 & $\mathbf{. 7 2}$ & & & & \\
\hline Satisfaction & 0.123 & 0.106 & 0.294 & 0.297 & 0.265 & 0.305 & 0.154 & $\mathbf{. 7 3}$ & & & \\
\hline Social & 0.377 & 0.1 & 0.055 & 0.105 & 0.327 & 0.235 & 0.102 & 0.16 & $\mathbf{. 9 9}$ & & \\
\hline shFreq & 0.416 & 0.219 & 0.31 & 0.197 & 0.648 & 0.341 & 0.187 & 0.272 & 0.259 & $\mathbf{. 7 3}$ & \\
\hline & & & & & & & & & & \multirow{2}{*}{} & \\
shFreqTrad & 0.353 & 0.169 & 0.258 & 0.282 & 0.566 & 0.344 & 0.216 & 0.226 & 0.316 & 0.683 & $\mathbf{. 7 1}$ \\
\hline
\end{tabular}

\subsection{Results for Structural Model}

The second step in PLS-SEM analysis tests the hypothesised relationships in the model. We evaluated the structural models for effects on information satisfaction using the coefficient of determination (R2) values and in terms of the significance and relative values of the path coefficients (Kishore and McLean 2007) (Gefen, Straub et al. 2000).

Figure 2 shows the R2 values, path coefficients, and their significance levels calculated by SmartPLS 2.0 beta (Ringle, Wende et al. 2005) that test the fundamental propositions of UGT. The model explains $41 \%$ of the variance in information satisfaction, indicating a moderate significant level of explanation (Hair Jr, Hult et al. 2013). Also, the social gratifications construct significantly influences the process gratifications construct, explaining $43 \%$ of its variance.

Figure 2: Uses and Gratifications Structural Research model for Political Information

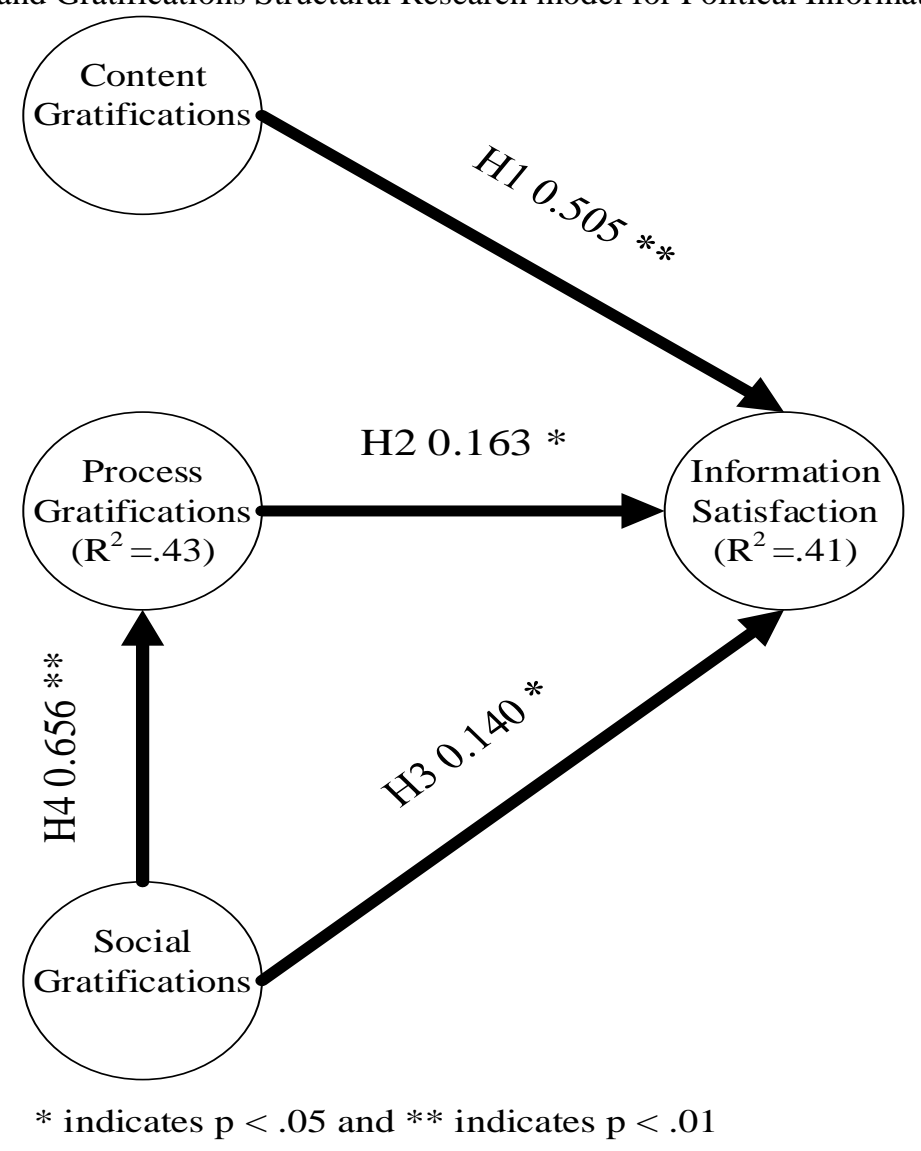




\section{Conclusion and Recommendations}

Support for all four hypotheses and explaining $41 \%$ of the variance in information satisfaction confirms that UGT is applicable for understanding information use in political situations, such as the elections in Tunisia in 2014.

In summary, our results suggest the following. First, higher perceptions of content gratifications, i.e., the accuracy and reliability of the information, are associated with higher perceptions of information satisfaction. Content gratifications has the largest effect of any construct on information satisfaction. Second, process gratifications, including the number of information activities and frequency of those activities, is predictive of information satisfaction, positively impacting information availability and how influential the information is perceived. Third, social gratifications contribute to satisfaction at similar levels as process gratifications, despite being partially mediated. Confirming the influence of this construct in our context.

Our results are consistent with UGT studies related to using the Internet (Stafford, Stafford et al. 2004, Lee and Ma 2012, Parmelee and Perkins 2012, Ku, Chu et al. 2013), social media (Lenhart and Madden 2007, Lee and Ma 2012, $\mathrm{Ku}$, Chu et al. 2013, Macafee 2013), and political information (Kaye and Johnson 2002, Kaye and Johnson 2004, Lariscy, Tinkham et al. 2011, Parmelee and Perkins 2012). Specifically, we support the theory by finding the constructs valid and reliable in data from another context. Further, we confirm primary hypotheses relating gratifications to information satisfaction.

The limitations of our study include our sample of students and our web-based survey methodology. We have implemented controls for the vulnerabilities of a web-based survey as described in the methods section and believe they have been addressed. Young people are substantive proportions of the population in Tunisia and other countries, indicating that understanding their views is important. Thus, our sample limits generalising beyond relatively wealthy young people. Yet, our participants experienced the uprising, were eligible to vote in the elections, and have substantive interests in the future of Tunisia.

Our study confirms that UGT applied to the use of information sources related to political situations with both traditional and Internet information sources. Communicators should note that information reliability is the primary influence on satisfaction, and therefore attempt to ensure they maintain a reputation for conveying accurate information. Individuals searching for political information should 1) determine how they'll know their information is accurate, 2) maximise the number of different activities for information-seeking rather than focusing on the frequency of a few activities, and 3) information sharing activities and frequency also contribute to information satisfaction.

\section{References}

- Agarwal, R. and E. Karahanna (2000). Time flies when you're having fun: Cognitive absorption and beliefs about information technology usage. MIS quarterly. CrossRef

- Bachmann, D., J. Elfrink and G. Vanazza (1996). Tracking the Progress of E-mail vs. Snail-mail. Marketing Research.

- Bailey, J. E. and S. W. Pearson (1983). Development of a Tool for Measuring and Analyzing Computer User Satisfaction."Management Science. $\underline{\text { CrossRef }}$

- Agarwal, R. and E. Karahanna (2000). Time flies when you're having fun: Cognitive absorption and beliefs about information technology usage."MIS quarterly. $\underline{\text { CrossRef }}$

- Bachmann, D., J. Elfrink and G. Vanazza (1996). Tracking the Progress of E-mail vs. Snail-mail. Marketing Research.

- Bailey, J. E. and S. W. Pearson (1983). Development of a Tool for Measuring and Analyzing Computer User Satisfaction. Management Science. $\underline{\text { CrossRef }}$

- Bassellier, G. and I. Benbasat (2004). Business competence of information technology professionals: conceptual development and influence on IT-business partnerships. MIS quarterly. $\underline{\text { CrossRef }}$

- $\quad$ Blumler, J. G. and D. McQuail (1969). Television in politics: Its uses and influence, University of Chicago Press.

- Bryant, S. M., J. E. Hunton and D. N. Stone (2004). Internet-based Experiments: Prospects and Possibilities for Behavioral Accounting Research. Behavioral Research in Accounting. CrossRef

- Chin, W. W. (1998). The partial least squares approach to structural equation modeling. Modern Methods for Business Research. G. A. Marcoulides. Mahway, New Jersey, Lawrence Erlbaum.

- Chung, C. J., Y. Nam and M. A. Stefanone (2012). Exploring online news credibility: The relative influence of traditional and technological factors. Journal of Computer - Mediated Communication. CrossRef 
- Coderre, G., A. Mathieu and N. St-Laurent (2005). Comparison of the Quality of Quantitative Data Obtained Through Telephone, Postal and Email Surveys. International Journal of Market Research . CrossRef

- Couper, M. (2000). Web Surveys: A Review of Issues and Approaches. Public Opinion Quarterly. CrossRef

- Cutler, N. E. and J. A. Danowski (1980). Process Gratification in Aging Cohorts. Journalism Quarterly. CrossRef

- Fornell, C. and D. Larcker (1981). Evaluating structural equation models with unobservable variables and measurement error. Journal of Marketing Research. CrossRef

- Gefen, D., D. Straub and M.-C. Boudreau (2000). Structural equation modeling and regression: Guidelines for research and practice. Communications of the AIS. CrossRef

- Gefen, D., D. Straub and M. Boudreau (2000). Structural Equation Modeling and Regression: Guidelines for Research Practice. Communications of the Association of Information Systems. CrossRef

- Gopal, A., R. P. Bostrom and W. W. Chin (1992). Applying adaptive structuration theory to investigate the process of group support systems use. Journal of Management Information Systems. CrossRef

- Hair Jr, J. F., G. T. M. Hult, C. Ringle and M. Sarstedt (2013). A primer on partial least squares structural equation modeling (PLS-SEM), Sage Publications.

- Ji, P. and W. Wayne Fu (2013). Love Internet, love online content: Predicting Internet affinity with information gratification and social gratifications. Internet Research. $\underline{\text { CrossRef }}$

- Katz, E. (1987). Communication research since Lazarsfeld . Public Opinion Quarterly. CrossRef

- Katz, E., J. G. Blumler and M. Gurevitch (1973). Uses and gratifications research. Public opinion quarterly. $\underline{\text { CrossRef }}$

- Katz, E. and P. F. Lazarsfeld (1955). Personal influence: the part played by people in the flow of mass communications. Glencoe, IL, Free Press.

- $\quad$ Kaye, B. K. and T. J. Johnson (2002). Online and in the know: Uses and gratifications of the web for political information. Journal of Broadcasting \& Electronic Media. CrossRef

- Kaye, B. K. and T. J. Johnson (2004). A Web for all reasons: uses and gratifications of Internet components for political information. Telematics and Informatics. CrossRef

- $\quad$ Kishore, R. and E. R. McLean (2007). Reconceptualizing innovation compatibility as organizational alignment in secondary IT adoption contexts: an investigation of software reuse infusion. Engineering Management, IEEE Transactions. CrossRef

- Kraut, R., S. Kiesler, B. Bonka, J. Cummings, V. Helgeson and A. Crawford (2002). Internet Paradox Revisited. Journal of Social Issues. CrossRef

- Ku, Y.-C., T.-H. Chu and C.-H. Tseng (2013). Gratifications for using CMC technologies: A comparison among SNS, IM, and e-mail. Computers in Human Behavior. CrossRef

- $\quad$ Lariscy, R. W., S. F. Tinkham and K. D. Sweetser (2011). Kids these days: Examining differences in political uses and gratifications, Internet political participation, political information efficacy, and cynicism on the basis of age. American Behavioral Scientist.

- Lazar, J. and J. Preece (1999). Designing and Implementing Web-based Surveys. Journal of Computer Information Systems.

- Lee, C. S. and L. Ma (2012). News sharing in social media: The effect of gratifications and prior experience. Computers in Human Behavior. $\underline{\text { CrossRef }}$

- Lenhart, A. and M. Madden (2007). Social networking websites and teens: An overview. Washington, DC, Pew Internet \& American Life.

- Lin, C. A. (2002). Perceived gratifications of online media service use among potential users. Telematics and Informatics. CrossRef

- Macafee, T. (2013). Some of these things are not like the others: Examining motivations and political predispositions among political Facebook activity. Computers in Human Behavior. CrossRef

- McKinney, V., K. Yoon and F. Zahedi (2002). The Measurement of Web-Customer Satisfaction: An Expectation and Disconfirmation Approach. Information Systems Research. CrossRef

- Muhtaseb, A. and L. R. Frey (2008). Arab Americans' motives for using the Internet as a functional media alternative and their perceptions of US public opinion. Journal of Computer - Mediated Communication. CrossRef

- Netemeyer, R. G., M. W. Johnston and S. Burton (1990). Analysis of role conflict and role ambiguity in a structural equations framework. Journal of Applied Psychology. CrossRef

- Nunnally, J. Bernstein, IH (1994). Psychometric theory, New York: McGraw-Hill. 
- Parmelee, J. H. and S. C. Perkins (2012). Exploring social and psychological factors that influence the gathering of political information online. Telematics and Informatics. CrossRef

- Punter, T., M. Ciolkowski, B. Freimut and I. John (2003). Conducting On-Line Surveys in Software Engineering. Proceedings of the International Symposium on Empirical Software Engineering (ISESE '03), Washington, DC, IEEE Computer Society. CrossRef

- $\quad$ Ringle, C. M., S. Wende and A. Will (2005). SmartPLS 2.0 (beta), Hamburg.

- Ruggiero, T. E. (2000). Uses and gratifications theory in the 21 st century. Mass communication \& society. CrossRef

- Singer, J. and N. G. Vinson (2002). Ethical Issues in Empirical Studies of Software Engineering. IEEE Transactions on Software Engineering. CrossRef

- $\quad$ Stafford, T. F., M. R. Stafford and L. L. Schkade (2004). Determining uses and gratifications for the Internet. Decision Sciences. CrossRef

- Staples, D. S. and P. Seddon (2004). Testing the technology-to-performance chain model. Journal of Organizational and End User Computing (JOEUC). CrossRef

- Whitley, B. (2002). Principles of Research in Behavioral Science. New York, McGraw-Hill.

- Wixom, B. H. and P. A. Todd (2005). A theoretical integration of user satisfaction and technology acceptance. Information Systems Research. CrossRef 